\title{
Novel Tetrazole-Based Antimicrobial Agents Targeting Clinical Bacteria Strains: Exploring the Inhibition of Staphylococcus aureus DNA Topoisomerase IV and Gyrase
}

\author{
Piotr Roszkowski $\left.{ }^{1}{ }^{(}\right)$, Jolanta Szymańska-Majchrzak $\left.{ }^{2}{ }^{(}\right)$, Michał Koliński $\left.{ }^{3}{ }^{(}\right)$, Sebastian Kmiecik ${ }^{4}(\mathbb{D}$, \\ Małgorzata Wrzosek ${ }^{5}\left(\mathbb{D}\right.$, Marta Struga ${ }^{2} \mathbb{D}$ and Daniel Szulczyk ${ }^{2, *} * \mathbb{C}$
}

Citation: Roszkowski, P. Szymańska-Majchrzak, J.; Koliński,

M.; Kmiecik, S.; Wrzosek, M.;

Struga, M.; Szulczyk, D. Novel Tetrazole-Based Antimicrobial Agents Targeting Clinical Bacteria Strains: Exploring the Inhibition of Staphylococcus aureus DNA

Topoisomerase IV and Gyrase. Int. J. Mol. Sci. 2022, 23, 378. https:// doi.org/10.3390/ijms23010378

Academic Editor: Michał Arabski

Received: 3 December 2021

Accepted: 28 December 2021

Published: 29 December 2021

Publisher's Note: MDPI stays neutral with regard to jurisdictional claims in published maps and institutional affiliations.

Copyright: (C) 2021 by the authors. Licensee MDPI, Basel, Switzerland. This article is an open access article distributed under the terms and conditions of the Creative Commons Attribution (CC BY) license (https:// creativecommons.org/licenses/by/ $4.0 /)$
1 Faculty of Chemistry, University of Warsaw, Pasteura 1, 02-093 Warszawa, Poland; roszkowski@chem.uw.edu.pl

2 Chair and Department of Biochemistry, Medical University of Warsaw, 02-097 Warszawa, Poland; jolanta.szymanska@wum.edu.pl (J.S.-M.); marta.struga@wum.edu.pl (M.S.)

3 Bioinformatics Laboratory, Mossakowski Medical Research Institute, Polish Academy of Sciences, 5 Pawinskiego St., 02-106 Warsaw, Poland; mkolinski@imdik.pan.pl

4 Biological and Chemical Research Centre, Faculty of Chemistry, University of Warsaw, 02-089 Warsaw, Poland; sekmi@chem.uw.edu.pl

5 Department of Biochemistry and Pharmacogenomics, Faculty of Pharmacy, Medical University of Warsaw, 02-097 Warsaw, Poland; malgorzata.wrzosek@wum.edu.pl

* Correspondence: daniel.szulczyk@wum.edu.pl

\begin{abstract}
Eleven novel imide-tetrazoles were synthesized. In the initial stage of research, in silico structure-based pharmacological prediction was conducted. All compounds were screened for antimicrobial activity using standard and clinical strains. Within the studied group, compounds 1-3 were recognized as leading structures with the most promising results in antimicrobial studies. Minimal inhibitory concentration values for compounds 1, 2, 3 were within the range of $0.8-3.2 \mu \mathrm{g} / \mathrm{mL}$ for standard and clinical Gram-positive and Gram-negative bacterial strains, showing in some cases higher activity than the reference Ciprofloxacin. Additionally, all three inhibited the growth of all clinical Staphylococci panels: Staphylococcus aureus (T5592; T5591) and Staphylococcus epidermidis (5253; 4243) with MIC values of $0.8 \mu \mathrm{g} / \mathrm{mL}$. Selected compounds were examined in topoisomerase IV decatenation assay and DNA gyrase supercoiling assay, followed by suitable molecular docking studies to explore the possible binding modes. In summary, the presented transition from substrate imide-thioureas to imide-tetrazole derivatives resulted in significant increase of antimicrobial properties. The compounds 1-3 proposed here provide a promising basis for further exploration towards novel antimicrobial drug candidates.
\end{abstract}

Keywords: antimicrobial; antibacterial; tetrazole; gyrase; topoisomerase

\section{Introduction}

Antibiotic resistance is mentioned as one of the most important health threats of present times. Increasing appearance of multi-drug-resistant organisms outside the hospital environment confirms their presence in our everyday life. The situation is worsening due to the lack of effective new antimicrobial molecules, and the inappropriate use of available antibiotics. Clinicians have limited appropriate therapeutic options for infected patients [1].

We can divide resistance mechanisms into two general categories, internal and acquired. Internal resistance mechanisms are most often associated with chromosomal coding. Such mechanisms include non-specific efflux pumps, enzymes that block action of antibacterial substances, and other mechanisms that are responsible for the permeability reduction of the antibiotic. The core genetic structure of the bacteria organism is responsible for the creation of these mechanisms. Typically, low level antibiotic resistance is observed when an internal mechanism dominates. However, in the population of immunocompromised 
patients, pathogens containing internal mechanisms can develop strong antibiotic resistance. Contrariwise, acquired resistance arises as a result of horizontal gene transfer (HGT), involving the process of plasmid-encoding specific efflux pumps and enzymes that are able to modify the antibiotic or its target. This type of resistance mechanism poses a much greater threat to bacteria-infected individuals. We can also use an alternative classification of antimicrobial resistance mechanisms, divided into: active drug efflux, drug inactivation, drug target modification, and drug absorption reduction [2-10].

The increase of morbidity and mortality is directly related to the limited number of therapeutic options that can be used by the patients struggling with antibiotic-resistant infections. Consecutively, this causes the need for longer treatments and possible extended hospitalizations, which are also linked with an increased total cost of patient recovery. Methicillin-resistant Staphylococcus aureus infections might be our greatest concern. The mortality caused by these strains remains at the level of approximately 20-40\% [11-13]. Staphylococci have developed very effective resistance mechanisms against the currently used antibiotics. Examples are shown in Table 1 [14]. The great need for development of new molecules active against these bacterial strains is undeniable.

Table 1. Examples of several of the $S$. aureus mechanisms of resistance to selected antibiotics.

\begin{tabular}{|c|c|c|c|c|}
\hline Antibiotic & Resistance Gene(s) & Gene Product(s) & Mechanism(s) of Resistance & Location(s) \\
\hline$\beta$-Lactams & $\begin{array}{l}\text { (1) blaZ } \\
\text { (2) } m e c A\end{array}$ & $\begin{array}{l}\text { (1) } \beta \text {-Lactamase } \\
\text { (2) PBP2a }\end{array}$ & $\begin{array}{l}\text { (1) Enzymatic hydrolysis of } \\
\quad \beta \text {-lactam nucleus } \\
\text { (2) Reduced affinity for PBP }\end{array}$ & $\begin{array}{l}\text { (1) Pl:Tn } \\
\text { (2) C:SCCmec }\end{array}$ \\
\hline Glycopeptides & $\begin{array}{l}\text { (1) Unknown (VISA) } \\
\text { (2) } \operatorname{VanH}_{\mathrm{A}}\end{array}$ & $\begin{array}{l}\text { (1) Altered peptidoglycan } \\
\text { (2) D-Ala-D-Lac }\end{array}$ & $\begin{array}{l}\text { (1) Trapping of vancomycin in } \\
\text { the cell wall } \\
\text { (2) Synthesis of dipeptide with } \\
\text { reduced affinity for } \\
\text { vancomycin }\end{array}$ & $\begin{array}{l}\text { (1) C } \\
\text { (2) Pl:Tn }\end{array}$ \\
\hline Quinolones & $\begin{array}{c}\text { (1) } \operatorname{parC} \\
\text { (2) } g y r A \text { or } g y r B\end{array}$ & $\begin{array}{l}\text { (1) ParC (or GrlA) } \\
\text { component of } \\
\text { topoisomerase IV } \\
\text { (2) GyrA or GyrB } \\
\text { components of gyrase }\end{array}$ & $\begin{array}{l}(1,2) \text { Mutations in the QRDR } \\
\text { region, reducing affinity of } \\
\text { enzyme-DNA complex for } \\
\text { quinolones }\end{array}$ & $\begin{array}{l}\text { (1) } \mathrm{C} \\
\text { (2) } \mathrm{C}\end{array}$ \\
\hline $\begin{array}{l}\text { Aminoglycosides (e.g., } \\
\text { gentamicin) Trimethoprim- } \\
\text { sulfamethoxazole } \\
\text { (TMP-SMZ) }\end{array}$ & $\begin{array}{l}\text { Aminoglycoside- } \\
\text { modifying enzymes (e.g., } \\
\text { aac, aph) } \\
\text { (1) Sulfonamide: sulA } \\
\text { (2) TMP: } d f r B\end{array}$ & $\begin{array}{c}\text { Acetyltransferase, } \\
\text { phosphotransferase } \\
\text { (1) Dihydropteroate } \\
\text { synthase } \\
\text { (2) Dihydrofolate } \\
\text { reductase (DHFR) }\end{array}$ & $\begin{array}{c}\text { Acetylating and/or } \\
\text { phosphorylating enzymes } \\
\text { modify aminoglycosides } \\
\text { (1) Overproduction of } \\
p \text {-aminobenzoic } \\
\text { acid by enzyme } \\
\text { (2) Reduced affinity for DHFR }\end{array}$ & $\begin{array}{l}\text { Pl, Pl:Tn } \\
\text { (1) C } \\
\text { (2) C }\end{array}$ \\
\hline Oxazolidinones & $r r n$ & $23 S$ rRNA & $\begin{array}{l}\text { Mutations in domain } \mathrm{V} \text { of } 23 \mathrm{~S} \\
\text { rRNA component of the } 50 \mathrm{~S} \\
\text { ribosome. } \\
\text { Interferes with ribosomal } \\
\text { binding }\end{array}$ & $\mathrm{C}$ \\
\hline $\begin{array}{l}\text { Quinupristin-dalfopristin } \\
\text { (Q-D) }\end{array}$ & $\begin{array}{l}\text { (1) Q: ermA, ermB, ermC } \\
\text { (2) D: vat, vatB }\end{array}$ & $\begin{array}{l}\text { (1) Ribosomal methylases } \\
\text { (2) Acetyltransferases }\end{array}$ & $\begin{array}{l}\text { (1) Reduce binding to the } 23 S \\
\text { ribosomal subunit } \\
\text { (2) Enzymatic modification of } \\
\text { dalfopristin }\end{array}$ & $\begin{array}{l}\text { (1) } \mathrm{Pl}, \mathrm{C} \\
\text { (2) } \mathrm{Pl}\end{array}$ \\
\hline
\end{tabular}

$\mathrm{Pl}$, plasmid; C, chromosome; $\mathrm{Tn}$, transposon; QRDR, quinolone resistance-determining region.

Details on mechanisms of bacteria strains resistance have been published in many papers [15-21] and further documents will be released in the future, since new outcomes will be observed. A common assumption from most of the publications is that there is a strong need for new antibacterial compounds that may be valuable in the treatment of bacterial infections resistant to commonly used antibiotics.

In previous years, our research group was devoted to searching for new tetrazole-based compounds with antimicrobial activity [22-25]. Clinicians use the tetrazole-derived antimicrobial drugs such as Cefamandole, Ceftezole, both second-generation broad-spectrum cephalosporin antibiotics, and the oxazolidinone-class antibiotic Tadalizolid. Tetrazole 
structural modification of compounds may increase antibacterial properties, which was observed in our studies. In this work, we decided to look for compounds with well-known activity against bacterial strains in our own compounds library. Based on earlier study results and currently developed research we have decided to design imide-tetrazole hybrid structures for antimicrobial evaluation. Our team is investigating a number of imides and their derivatives, reporting diverse structural and biological activities [26-28]. Thiourea derivatives of two imides with confirmed antimicrobial activity were used as substrates for the synthesis of tetrazole-imide hybrids [29,30]. Our previous studies showed that the introduction of tetrazole arrangement in thiourea derivatives leads to an increase of antimicrobial activity [22-25].

\section{Results and Discussion}

\subsection{In Silico Structure-Based Pharmacological Prediction}

\subsubsection{Antibacterial Activity}

Using AntiBac-Pred [31] web services of Way2Drug platform, activity against Grampositive and Gram-negative bacteria was predicted for eleven synthesized compounds. It was found that the whole group might be active against $S$. aureus, Bacillus subtilis, and Mycobacterium smegmatis strains. It should be mentioned, that interesting probability scores were found for compounds:

- 3 (confidence value 0.1880), 9 (confidence value 0.2211), and 12 (confidence value 0.1718) for activity against Staphylococcus aureus subsp. aureus MW2 resistant strain.

- $\quad 2$ (confidence value 0.1431 ) and 7 (confidence value 0.2540 ) for activity against Bacillus subtilis subsp. subtilis str. 168 strain.

- $\quad 2$ (confidence value 0.1158 ), 7 (confidence value 0.1011 ), and 9 (confidence value 0.1511 ) for activity against Mycobacterium smegmatis strain.

Probability scores should be considered as low, but the whole group of designed compounds showed potential activity against similar strains.

\subsubsection{Toxicological Parameters}

The pkCSM [32] software was used for evaluation of toxicological parameters in silico. Evaluation revealed that two of the synthesized compounds were positive in the AMES test, therefore should be recognized as carcinogenic. It should be mentioned that both contained $-\mathrm{NO}_{2}$ substituent attached to phenyl ring. It is commonly known that this moiety may lead to compounds with high toxicity. Furthermore, all derivatives except $\mathbf{1 0}$ were found to have the human Ether-à-go-go-Related Gene (hERG II) inhibitor, which is the principal cause of acquiring long QT syndrome. Results are consistent in terms of skin sensitization test; all compounds should not develop this effect. However, all compounds may increase hepatotoxicity. The maximum recommended tolerated dose (MRTD) for the whole group should be considered as low. It could be stated that in most tests the results (Table 2) are consistent for the synthesized compounds.

\subsection{Chemistry}

Eleven new $1 H$-tetrazol-5-amine derivatives were synthesized according to a well-known procedure [24]. Two types of thiourea derivatives were used. First possessing imide structure of 4,5,6,7-tetramethyl-3a,4,7,7a-tetrahydro-1 $H$-4,7-methanoisoindole-1,3(2H)-dione and second 4-isopropyl-7-methyl-3a,4,7,7a-tetrahydro-1H-4,7-ethanoisoindole-1,3(2H)-dione. Procedures for obtaining imides and suitable thiourea derivatives were reported [26,27]. Published papers contain physicochemical and biological evaluation results. The main goal in the current design was to replace the thiourea arrangement with a tetrazole scaffold. Our approach utilizes oxidative desulfurization of thiourea substrates followed by cyclization, using sodium azide as an external nucleophile. Mercury (II) chloride was used as a desulfurization agent. Mechanism of this reaction is known. This structural modification may lead to improvement of antimicrobial activity based on our previous experiments. Both reaction schemes and conditions are depicted below (Scheme 1). 
Table 2. The toxicological parameters of synthesized imide-tetrazole derivatives estimated using pkCSM software.

\begin{tabular}{|c|c|c|c|c|c|c|c|c|c|c|c|c|}
\hline Toxicological Test & Unit & 1 & 2 & 3 & 4 & 5 & 6 & 7 & 8 & 9 & 10 & 11 \\
\hline AMES toxicity & (Yes/No) & No & No & No & Yes & No & No & No & Yes & No & No & No \\
\hline $\begin{array}{l}\text { Max. tolerated dose } \\
\text { (human) }\end{array}$ & (log mg/kg/day) & 0.309 & 0.361 & 0.355 & -0.002 & 0.402 & 0.402 & 0.267 & -0.055 & 0.272 & -0.685 & 0.297 \\
\hline hERG I inhibitor & (Yes/No) & No & No & No & No & No & No & No & No & No & No & No \\
\hline hERG II inhibitor & (Yes/No) & Yes & Yes & Yes & Yes & Yes & Yes & Yes & Yes & Yes & No & Yes \\
\hline $\begin{array}{l}\text { Oral Rat Acute } \\
\text { Toxicity (LD50) }\end{array}$ & $(\mathrm{mol} / \mathrm{kg})$ & 2.749 & 2.589 & 2598 & 2.483 & 2.417 & 2.47 & 2.636 & 2.542 & 2.558 & 1.834 & 2.517 \\
\hline $\begin{array}{l}\text { Oral Rat Chronic } \\
\text { Toxicity (LOAEL) }\end{array}$ & (log mg/kg_bw/day) & 1.025 & 1.218 & 1.207 & 1.345 & 1.487 & 1.42 & 1.213 & 1.337 & 1.245 & 1.944 & 1.416 \\
\hline Hepatotoxicity & (Yes/No) & Yes & Yes & Yes & Yes & Yes & Yes & Yes & Yes & Yes & Yes & Yes \\
\hline Skin Sensitization & (Yes/No) & No & No & No & No & No & No & No & No & No & No & No \\
\hline T. Pyriformis toxicity & $(\log u g / L)$ & 0.294 & 0.297 & 0.297 & 0.287 & 0.301 & 0.3 & 0.29 & 0.286 & 0.291 & 0.29 & 0.291 \\
\hline Minnow toxicity & $(\log \mathrm{mM})$ & -0.453 & -0.621 & -0.767 & -1.597 & -0.913 & -0.306 & -0.95 & -1.914 & -1.606 & -2.571 & -0.635 \\
\hline
\end{tabular}

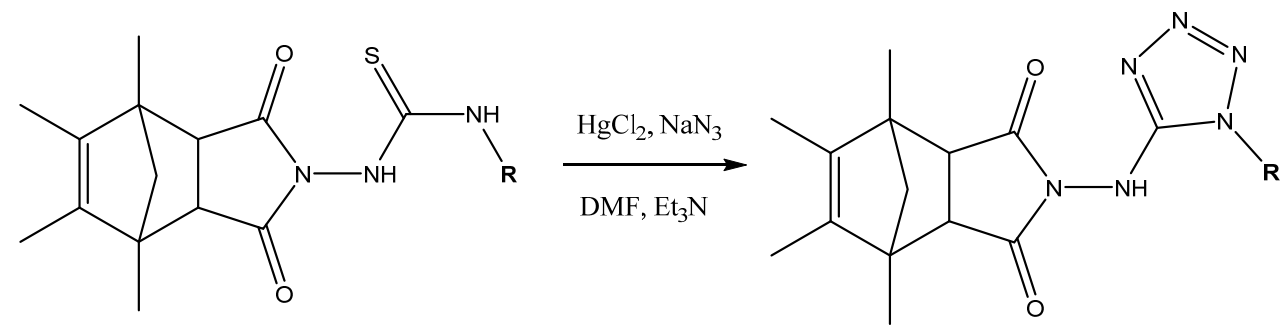

R:

\begin{tabular}{|l|l|l|l|l|l|}
\hline $\mathbf{1}$ & $\mathbf{2}$ & $\mathbf{3}$ & $\mathbf{4}$ & $\mathbf{5}$ & $\mathbf{6}$ \\
\hline $3-\mathrm{CF}_{3} \mathrm{Ph}$ & $2-\mathrm{ClPh}$ & $2-\mathrm{BrPh}$ & $4-\mathrm{NO}_{2} \mathrm{Ph}$ & $4-\mathrm{CH}_{3} \mathrm{Ph}$ & $\mathrm{Ph}$ \\
\hline
\end{tabular}
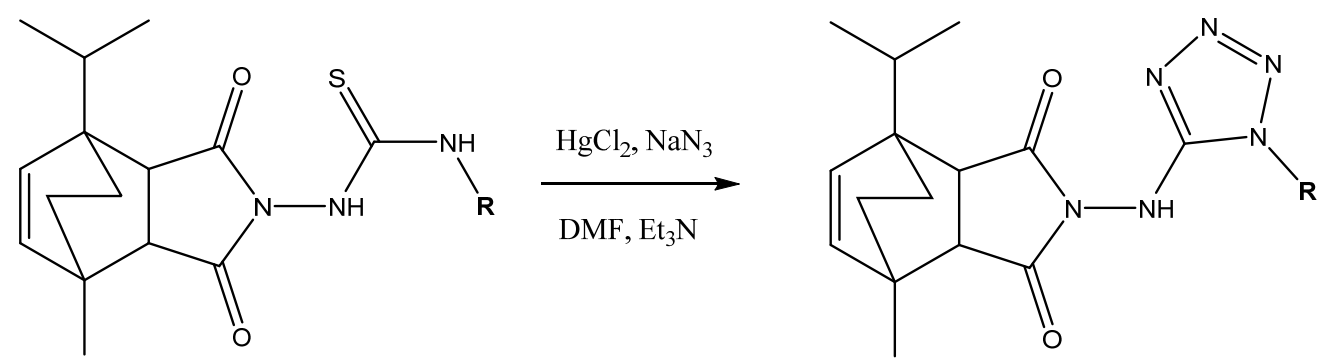

R:

\begin{tabular}{|l|l|l|l|l|}
\hline $\mathbf{7}$ & $\mathbf{8}$ & $\mathbf{9}$ & $\mathbf{1 0}$ & $\mathbf{1 1}$ \\
\hline $2-\mathrm{ClPh}$ & $4-\mathrm{NO}_{2} \mathrm{Ph}$ & $2-\mathrm{BrPh}$ & $4-\mathrm{CH}_{3} \mathrm{Ph}$ & $\mathrm{Ph}$ \\
\hline
\end{tabular}

Scheme 1. Transition from imide-thiourea substrates to imide-tetrazole hybrids.

All compounds were obtained in good yields. All eleven compounds were transferred for further physicochemical and biological evaluation.

\subsection{Biological Studies}

\subsubsection{In Vitro Antibacterial Activity Studies}

All synthesized compounds were tested in vitro against a set of bacteria, including representative standard Gram-positive and Gram-negative rods. Compounds were screened for their minimal inhibitory concentrations (MICs) [33]. As a result, 4 of 11 examined compounds: 5, 7, 9, and 11 demonstrated moderate antimicrobial activity against standard bacteria strains with MIC values ranging from 32 to $256 \mu \mathrm{g} / \mathrm{mL}$, while the rest of the tested compounds exhibited high and broad spectrum of activity within the range of 0.1-32 $\mu \mathrm{g} / \mathrm{mL}$ (Table 3). It is worth emphasizing that among this group, three compounds 
$(1,2,3)$ showed excellent antimicrobial profiles, especially against standard Gram-positive Staphylococci, within the range of $0.1-3.2 \mu \mathrm{g} / \mathrm{mL}$ and, in general, they were even more effective than the reference Ciprofloxacin. These three compounds were also found to be good inhibitors of the growth of Gram-negative rods: E. coli and P. aeruginosa, within the range of $0.4-25.6 \mu \mathrm{g} / \mathrm{mL}$, which indicates that compounds $1,2,3$ are the most promising of all synthesized derivatives.

Table 3. Activity of compounds against standard bacteria strains, expressed by minimal inhibitory concentrations $(\mu \mathrm{g} / \mathrm{mL})$.

\begin{tabular}{|c|c|c|c|c|c|c|c|c|c|c|c|c|}
\hline \multirow[b]{2}{*}{ Strain } & \multicolumn{10}{|c|}{ Compound $(\mu \mathrm{g} / \mathrm{mL})$} & \multirow[b]{2}{*}{11} & \multirow[b]{2}{*}{$\begin{array}{c}\text { Ciprofloxacin } \\
(\mu \mathrm{g} / \mathrm{mL})\end{array}$} \\
\hline & 1 & 2 & 3 & 4 & 5 & 6 & 7 & 8 & 9 & 10 & & \\
\hline S. aureus NCTC 4163 & 0.2 & 0.4 & 0.1 & 16 & $>256$ & 2 & 32 & 8 & 64 & 4 & 128 & 0.125 \\
\hline S. aureus ATCC 25923 & 0.2 & 0.4 & 0.1 & 8 & $>256$ & 2 & 32 & 8 & 64 & 4 & 128 & 0.5 \\
\hline S. aureus ATCC 6538 & 0.2 & 0.4 & 0.2 & 32 & $>256$ & 2 & 32 & 8 & 64 & 4 & 128 & 0.25 \\
\hline S. aureus ATCC 29213 & 0.2 & 0.8 & 0.2 & 16 & $>256$ & 4 & 64 & 8 & 64 & 8 & 128 & 0.25 \\
\hline S. epidermidis ATCC 12228 & 3.2 & 3.2 & 2 & 32 & $>256$ & 16 & 128 & 16 & 128 & 32 & 256 & 0.25 \\
\hline S. epidermidis ATCC 35984 & 0.2 & 0.4 & 0.2 & 32 & $>256$ & 4 & 32 & 16 & 64 & 8 & 128 & 0.125 \\
\hline E. coli ATCC 25922 & 0.4 & 1.6 & 0.4 & 256 & $>256$ & 8 & 128 & $>256$ & 128 & 16 & $>256$ & 0.015 \\
\hline P. aeruginosa ATCC 15442 & 12.8 & 25.6 & 16 & $>256$ & $>256$ & $>256$ & $>256$ & $>256$ & $>256$ & $>256$ & $>256$ & 0.125 \\
\hline
\end{tabular}

In the next stage of the experiment, 8 of 11 compounds were selected for a clinical strain activity evaluation against $S$. aureus, S. epidermidis, E. coli, K. pneumoniae, and P. aeruginosa. In general, the antimicrobial activity of tested compounds against hospital strains of bacteria is comparable to standard strains (Table 4). MIC values for compounds 4, 6, 8, 9, 10 range from 2 to $32 \mu \mathrm{g} / \mathrm{mL}$ against Gram-positive strains; however, compound 9 showed better results against all tested clinical microorganisms, including Gram-negative rods. MIC values for compounds 1, 2, 3 are within the range of $0.8-3.2 \mu \mathrm{g} / \mathrm{mL}$. Additionally, all three inhibited the growth of all clinical Staphylococci panels: S. aureus (T5592; T5591) and S. epidermidis $(5253 ; 4243)$ with MIC values of $0.8 \mu \mathrm{g} / \mathrm{mL}$.

Table 4. Activity of the selected derivatives against clinical isolates, expressed by minimal inhibitory concentrations $(\mu \mathrm{g} / \mathrm{mL})$.

\begin{tabular}{|c|c|c|c|c|c|c|c|c|c|}
\hline \multirow[b]{2}{*}{ Strain } & \multicolumn{8}{|c|}{ Compound ( $\mu \mathrm{g} / \mathrm{mL})$} & \multirow[b]{2}{*}{$\begin{array}{c}\text { Ciprofloxacin } \\
(\mu \mathrm{g} / \mathrm{mL})\end{array}$} \\
\hline & 1 & 2 & 3 & 4 & 6 & 8 & 9 & 10 & \\
\hline S. epidermidis 5253 & 0.8 & 0.8 & 0.8 & 16 & 4 & 16 & 4 & 16 & 0.25 \\
\hline S. epidermidis 4243 & 0.8 & 0.8 & 0.8 & 32 & 4 & 16 & 2 & 8 & 0.13 \\
\hline S. aureus T5592 & 0.8 & 0.8 & 0.8 & 16 & 4 & 16 & 4 & 16 & 0.25 \\
\hline S. aureus T5591 & 0.8 & 0.8 & 0.8 & 32 & 4 & 16 & 4 & 16 & 0.25 \\
\hline E. coli 520 & 3.2 & 3.2 & 1.6 & 256 & 8 & $>256$ & 8 & 32 & 0.06 \\
\hline E. coli 600 & 3.2 & 1.6 & 1.6 & 256 & 8 & $>256$ & 8 & 32 & 0.03 \\
\hline K. pneumoniae 510 & 3.2 & 3.2 & 3.2 & 256 & 16 & $>256$ & 16 & 32 & 4 \\
\hline P. aeruginosa 659 & 1.6 & 1.6 & 1.6 & 256 & 16 & $>256$ & 16 & 32 & 0.5 \\
\hline
\end{tabular}

In general, the experiment revealed that derivatives of 1,5-disubstituted tetrazole-imides containing 4,5,6,7-tetramethyl moiety exhibit better antimicrobial properties than those with 4-isopropyl-7-methyl imide scaffold. As an exception, compound 10 was more potent than compound 5 against most of the examined standard and clinical bacterial strains.

Regardless of the imide moiety kind, the presence of the electron-withdrawing nitro substituent in compounds 4 and 8 shows similar antimicrobial properties against the Gram-positive bacterial strains only. What is interesting is that usually nitro substituent 
induces toxicity of compound and may increase antimicrobial activity of the subjected for evaluation derivative. On the other hand, introduction of the chlorine substituent into ortho position to the phenyl ring in compounds $\mathbf{2}$ and $\mathbf{7}$ resulted in an antimicrobial activity increase, especially in the case of tetrazole-imides containing the 4,5,6,7-tetramethyl moiety. Exchange of the chlorine into bromine substituent in ortho position of the phenyl ring in compound 3 improved the inhibition of bacterial strains growth. Due to the significant electronegativity of the electron-withdrawing trifluoromethyl substituent in the phenyl ring, compound 1 exhibits high and broad antimicrobial activity against all tested strains. Derivatives possessing strong $\left(-\mathrm{CF}_{3}\right)$ and weak $(-\mathrm{Br},-\mathrm{Cl})$ deactivating electron-withdrawing substituents in the benzene ring turned out to have the highest antimicrobial potential of all tested compounds against standard and clinical strains of bacteria. Our previous evaluation of similar compounds showed that in general, electron-donating groups (EDG) attached to phenyl ring or lack of substituent were responsible for a decrease of antibacterial activity.

One of the study's goals was to determine superior imide moiety (4,5,6,7-tetramethyl in compounds 1-6 or 4-isopropyl-7-methyl in compounds 7-11). Containing 4,5,6,7tetramethyl moiety, derivatives $\mathbf{1}, \mathbf{2}$, and 3 showed significant antimicrobial results. In the second group of synthesized compounds, we observed no similar leading structures. Finally, the primary outcome of the study was achieved. Transition from substrate imidethioureas [29] to imide-tetrazole derivatives resulted in a spectacular increase of antimicrobial properties. Most of the substrates were inactive against standard bacteria strains; for only four (out of twenty-six derivatives), good activity was established. Such synthetic transition followed by antimicrobial activity improvement is depicted below (Scheme 2).

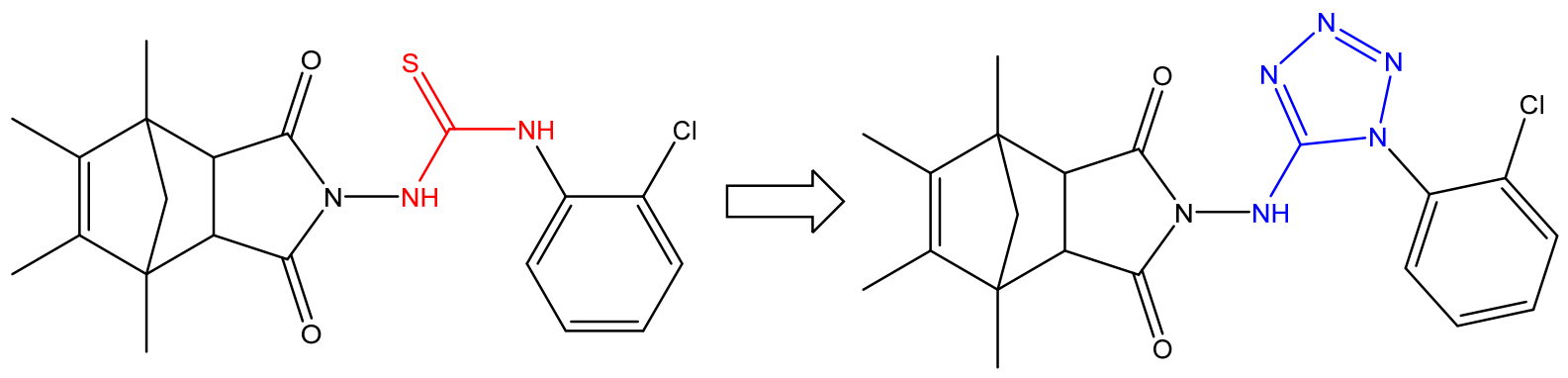

Not active

MIC $0.8-3.2 \mu \mathrm{g} / \mathrm{mL}$

Scheme 2. Example of structural modification leading to high activity against bacterial strains.

Lead compounds 1, 2, 3 were transferred for further testing to establish mechanism of antimicrobial action.

\subsubsection{Inhibition of Catalytic Activities of S. aureus Topoisomerases}

Topoisomerase IV is a bacterial type topoisomerase that is essential for proper chromosome segregation. It is the primary target of second-generation fluoroquinolones, such as Ciprofloxacin and Levofloxacin. Another type of bacterial type II topoisomerase is DNA gyrase. In general, it is supposed that in Gram-positive bacteria species, topoisomerase IV rather than DNA gyrase appears to be the primary target of most quinolone-based antibiotics. In this work, the influence of tetrazole derivatives was tested for both topoisomerase IV and DNA gyrase.

Selected compounds with the highest antimicrobial activity 1, 2, 3 were examined in topoisomerase IV decatenation assay (Figure 1) and DNA gyrase supercoiling assay (Figure 2). 


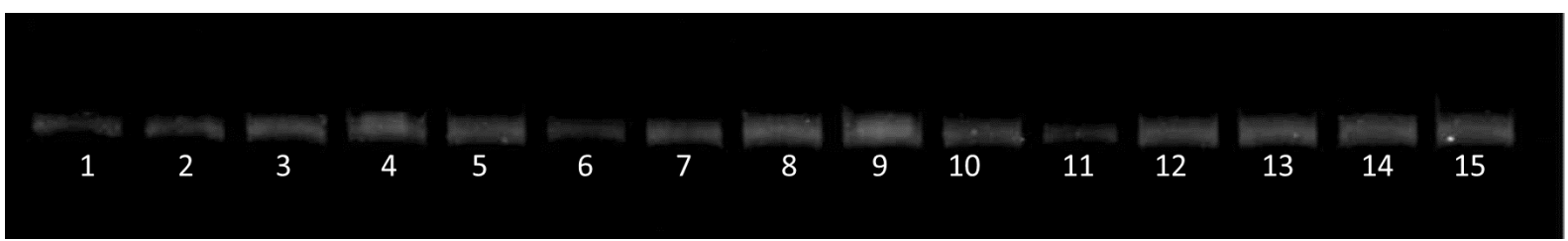

Figure 1. The effect of tested compounds on S. aureus topoisomerase IV activity. Decreasing amounts of 1, 2, or 3 were incubated with $200 \mathrm{ng}$ kinetoplast DNA and run-on agarose gel. Lane: 1-5: compound 3 at concentrations 64, 32, 8, 2, $0.5 \mu \mathrm{g} / \mathrm{mL}$, respectively. Lane: 6-10: compound 2 at concentrations $64,32,8,2,0.5 \mu \mathrm{g} / \mathrm{mL}$, respectively. Lane: 11-15: compound 1 at concentrations 64 , $32,8,2,0.5 \mu \mathrm{g} / \mathrm{mL}$, respectively.

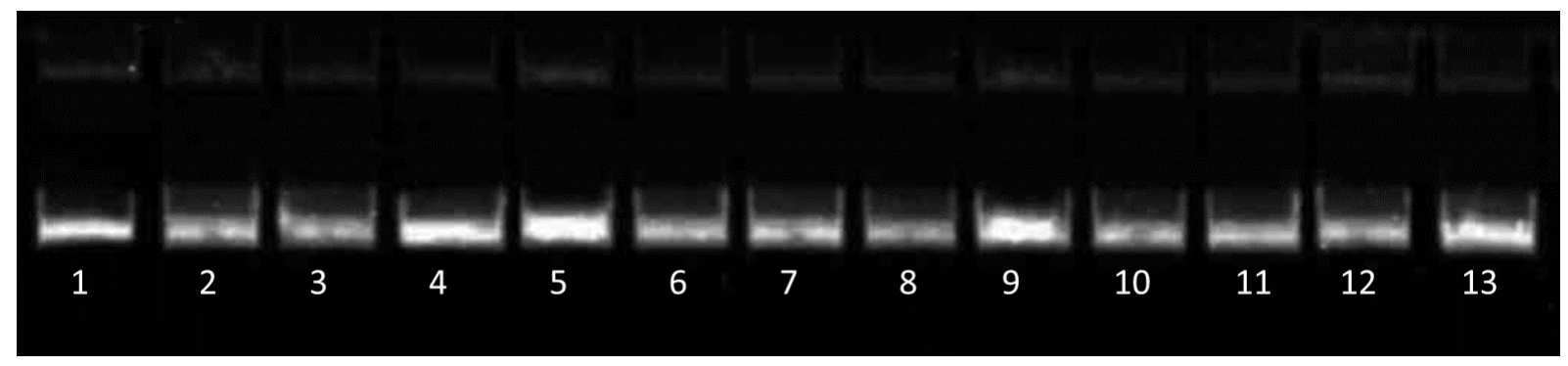

Figure 2. The influence of tested compounds on S. aureus DNA gyrase activity. Decreasing amounts of 1, 2, or 3 were incubated with supercoiled pBR322 plasmid DNA (500 ng) and run-on agarose gel. Lane 1: S. aureus DNA gyrase assay with DMSO (control). Lane: 2-5: compound 3 at concentrations 64, 32, 8, $2 \mu \mathrm{g} / \mathrm{mL}$, respectively. Lane: 6-9: compound 2 at concentrations $64,32,8,2 \mu \mathrm{g} / \mathrm{mL}$, respectively. Lane: 10-13: compound 1 at concentrations $64,32,8,2 \mu \mathrm{g} / \mathrm{mL}$, respectively.

The main outcome of the study is that compounds were able to inhibit the activity of bacterial gyrase and topoisomerases IV from $S$. aureus. The half minimal inhibitory concentration $\left(\mathrm{IC}_{50}\right)$ results (see Table 5 ) for bacterial topoisomerases were higher than reference Ciprofloxacin and Moxifloxacin.

Table 5. The affinity of selected compounds towards bacterial type II topoisomerases, expressed as $\mathrm{IC}_{50} \pm \mathrm{SEM}(\mu \mathrm{g} / \mathrm{mL})$.

\begin{tabular}{ccc}
\hline Compounds & $\begin{array}{c}\text { IC }_{50} \pm \text { S.E.M. for } \\
\text { Topoisomerase IV }(\mu \mathrm{g} / \mathrm{mL})\end{array}$ & $\begin{array}{c}\text { IC }_{50} \pm \text { S.E.M. for DNA } \\
\text { Gyrase }(\mu \mathrm{g} / \mathrm{mL})\end{array}$ \\
\hline Ciprofloxacin & $1.70 \pm 0.15$ & $3.55 \pm 0.13$ \\
\hline Moxifloxacin & $0.9 \pm 0.1$ & $12.05 \pm 0.50$ \\
\hline $\mathbf{1}$ & $63.2 \pm 4.2$ & $32.06 \pm 4.04$ \\
\hline $\mathbf{2}$ & $58.4 \pm 3.5$ & $37.52 \pm 9.72$ \\
\hline $\mathbf{3}$ & $61.2 \pm 2.1$ & $45.43 \pm 3.54$ \\
\hline
\end{tabular}

Moreover, the presented $\mathrm{IC}_{50}$ values suggest that there is a higher affinity towards the DNA gyrase of synthesized derivatives. What needs to be stated is that $\mathrm{IC}_{50}$ values obtained in in vitro study showed indecisive levels of affinity towards topoisomerases. There are significant structural differences between synthesized compounds and fluoroquinolones such as reference Ciprofloxacin and Moxifloxacin. There is a possibility that the antimicrobial mechanism of action can be dual (two preferred binding places of topoisomerase) or related to another antibacterial mode of action. 


\subsection{Molecular Docking}

To gain some insight into the possible binding modes, we conducted molecular docking of the studied compounds 1, 2, and 3 (the docking procedure is described in the Methods section).

The docking was carried out in two stages. First to the binding site targeted by fluoroquinolones (e.g., Ciprofloxacin, see our previous works [34]. The fluoroquinolones bind to the DNA-enzyme complex and stabilize it in the cleaved DNA state. The molecular docking to the fluoroquinolone binding site (using the crystal structure of the DNA gyrase in complex with DNA, PDB ID: 5BTC) showed that the narrow binding cleft is not wellsuited to the docked ligands. Namely, the cleft requires a planar ligand structure, such as Ciprofloxacin, rather than non-flat 1-3 compounds.

In addition to the fluoroquinolone inhibitor, there are also ATP-competitive inhibitors that target the B subunit of DNA gyrase with Novobiocin as the best-studied representative. Thus, in the second stage, we targeted the ATP-binding site. In docking, Staphylococcus aureus DNA Gyrase subunit B (crystal structure in complex with Novobiocin; PDB ID: 4URO) has been used. The docking results show that the docked 1-3 compounds occupy the ATP binding site with favorable binding energy (with ligand 1 showing a slightly higher preference for binding than other ligands, see Table 6 and Figure 3). In comparison to the Novobiocin-binding mode, the ligands mainly bind to the gyrase site that is responsible for interactions with the sugar Novobiocin moiety. In summary, the presented docking results indicate the possibility of binding to the ATP site; however, this binding mode requires further experimental confirmation.

Table 6. Docking results characterized by number of structures in the largest cluster and binding energy.

\begin{tabular}{ccc}
\hline Ligand (Compound) & $\begin{array}{c}\text { Number of Structures in the } \\
\text { Largest Cluster }\end{array}$ & Binding Energy \\
\hline $\mathbf{3}$ & 598 & $-5.09[\mathrm{kcal} / \mathrm{mol}]$ \\
\hline $\mathbf{2}$ & 609 & $-4.97[\mathrm{kcal} / \mathrm{mol}]$ \\
\hline $\mathbf{1}$ & 818 & $-5.58[\mathrm{kcal} / \mathrm{mol}]$ \\
\hline
\end{tabular}

(a)

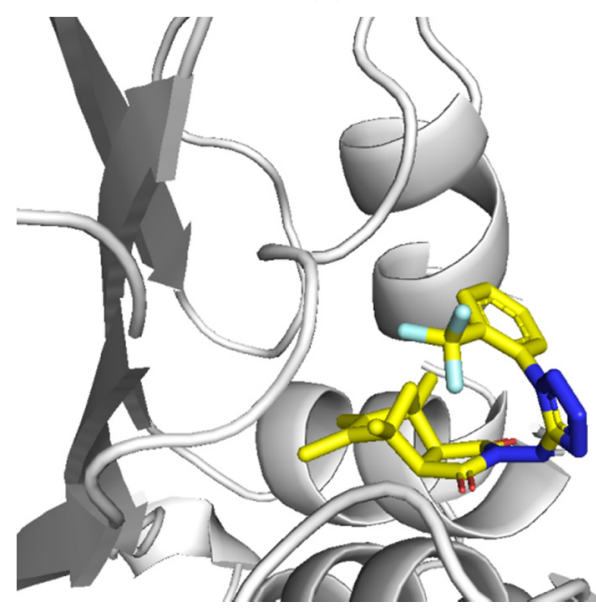

(b)

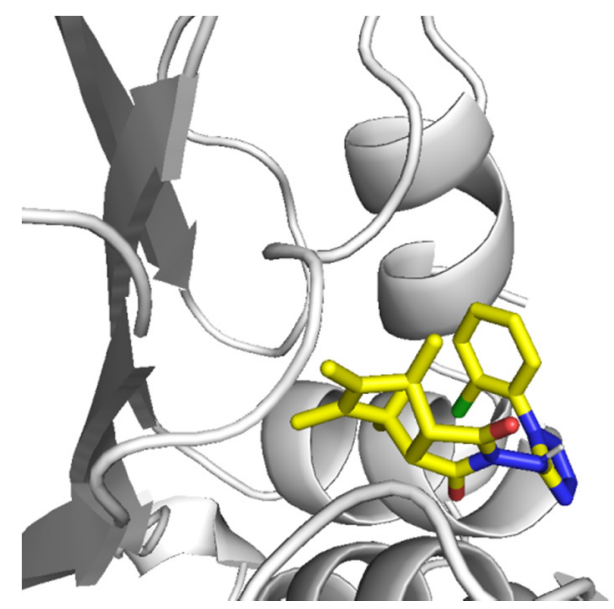

Figure 3. Cont. 
(c)

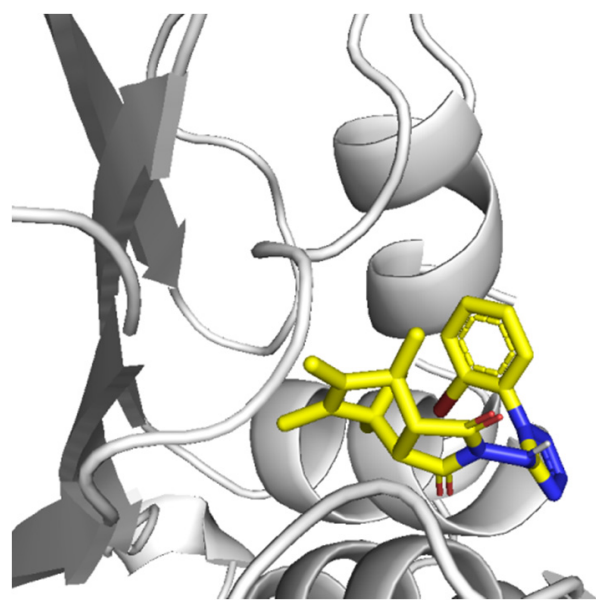

(e)

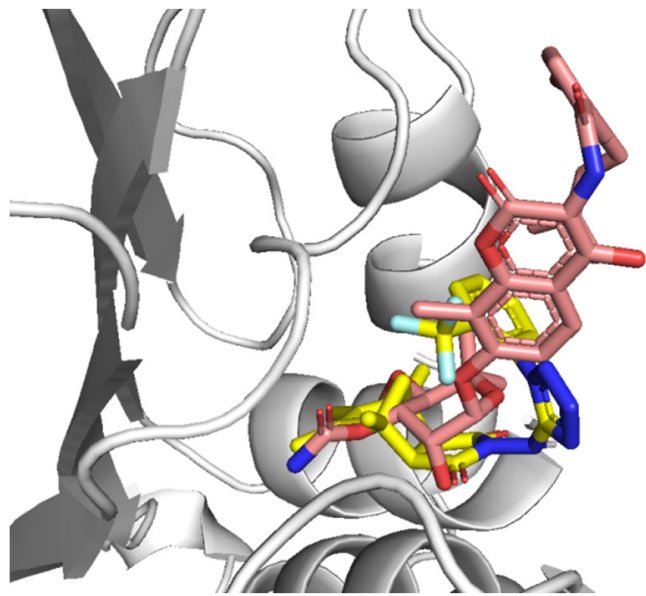

(d)

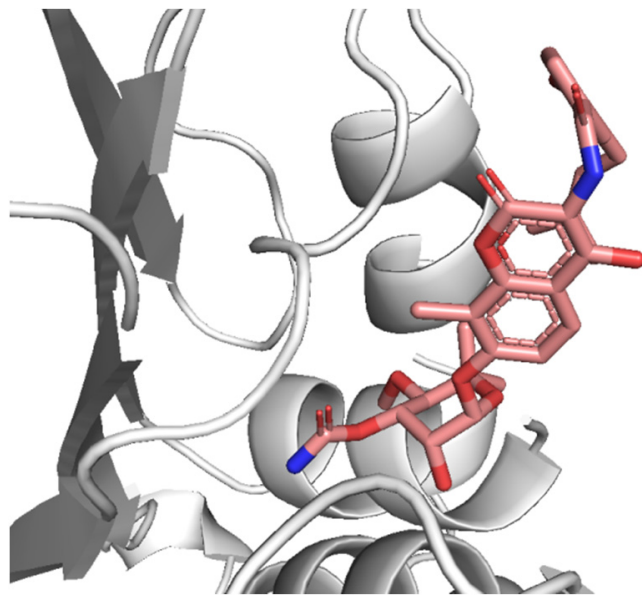

(f)

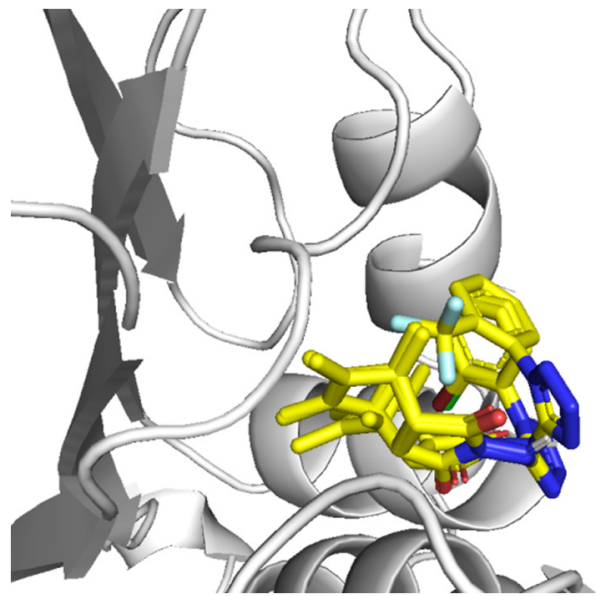

Figure 3. Molecular docking results and comparison to the Novobiocin-gyrase complex. (a) 1, (b) 2, (c) 3, (d) Novobiocin (PDB ID: 4URO), (e) comparison of $\mathbf{1}$ and Novobiocin, (f) comparison of 1, 2, and 3 ligands.

\section{Materials and Methods}

\subsection{Apparatus, Materials, and Analysis}

The reagents were supplied from Alfa Aesar (Haverhill, MA, USA) or Sigma Aldrich (Saint Louis, MO, USA). Organic solvents (acetonitrile, DMF, chloroform, and methanol) were supplied from POCh (Polskie Odczynniki Chemiczne, Gliwice, Poland). All chemicals were of analytical grade. Before use, dried DMF and acetonitrile were kept in crown cap bottles over anhydrous phosphorus pentoxide (Carl Roth, Karlsruhe, Germany).

The NMR spectra were recorded on a Bruker AVANCE DMX400 (Bruker, Billerica, MA, USA) spectrometer, operating at 500 or $300 \mathrm{MHz}\left({ }^{1} \mathrm{H}\right.$ NMR) and 125 or $75 \mathrm{MHz}\left({ }^{13} \mathrm{C} \mathrm{NMR}\right)$. The chemical shift values are expressed in ppm relative to TMS as an internal standard. Mass spectral ESI measurements were carried out on Waters ZQ Micro-mass instruments (Waters, Milford, MA, USA) with a quadrupole mass analyzer. The spectra were performed in the positive ion mode at a declustering potential of 40-60 V. The sample was previously separated on a UPLC column (C18) using the UPLC ACQUITYTM system by Waters connected with a DPA detector. Flash chromatography was performed on Merck silica gel 60 (200-400 mesh) using chloroform/methanol (19:1 vol) mixture as eluent. Analytical TLC was carried out on silica gel F254 (Merck) plates (0.25 mm thickness). 
3.2. Imide-Tetrazole Hybrids Preparation: Derivatives of

$3 a, 4,7,7 a-T e t r a h y d r o-1 H-4,7-m e t h a n o i s o i n d o l e-1,3(2 H)$-dione and

4-Isopropyl-7-methyl-3a,4,7,7a-tetrahydro-1H-4,7-ethanoisoindole-1,3(2H)-dione

Triethylamine (503 $\mu \mathrm{L}, 3.75 \mathrm{mmol}, 1-3$ drops) was added to a suspension of a corresponding thiourea substrate $(1.25 \mathrm{mmol})$, sodium azide $(244 \mathrm{mg}, 3.75 \mathrm{mmol})$, and mercuric chloride (373 mg, $1.38 \mathrm{mmol})$ in $20 \mathrm{~mL}$ of dry DMF. The resulting suspension was stirred for $6 \mathrm{~h}$ at room temperature or until TLC indicated complete consumption of starting material. The suspension was filtered through a pad of celite, washing with $\mathrm{CH}_{2} \mathrm{Cl}_{2}$. The filtrate was diluted with water, and extracted with $3 \times 15 \mathrm{~mL}$ of $\mathrm{CH}_{2} \mathrm{Cl}_{2}$. The combined organics were dried over $\mathrm{MgSO}_{4}$, filtered, and concentrated under reduced pressure. The resulting residue was purified by silica gel chromatography.

3.2.1. 4,5,6,7-Tetramethyl-2-((1-(3-(trifluoromethyl)phenyl)-1H-tetrazol-5-yl)amino)3a, 4,7,7a-tetrahydro-1H-4,7-methanoisoindole-1,3(2H)-dione (1)

Yield 68\%. ${ }^{1} \mathrm{H}$ NMR (300 MHz, DMSO-d 6 ): $\delta 1.25\left(\mathrm{~d}, J=8.1 \mathrm{~Hz}, 1 \mathrm{H}, \mathrm{CH}_{2}\right), 1.37(\mathrm{~s}$, $\left.6 \mathrm{H}, 2 \times \mathrm{CH}_{3}\right), 1.47\left(\mathrm{~d}, J=8.4 \mathrm{~Hz}, 1 \mathrm{H}, \mathrm{CH}_{2}\right), 1.50\left(\mathrm{~s}, 6 \mathrm{H}, 2 \times \mathrm{CH}_{3}\right), 3.05(\mathrm{~s}, 2 \mathrm{H}, 2 \times \mathrm{CH}), 7.38(\mathrm{~d}$, $J=7.8 \mathrm{~Hz}, 1 \mathrm{H}, \mathrm{ArH}), 7.51(\mathrm{t}, J=7.9 \mathrm{~Hz}, 1 \mathrm{H}, \mathrm{ArH}), 7.66(\mathrm{~d}, J=8.1 \mathrm{~Hz}, 1 \mathrm{H}, \mathrm{ArH}), 7.90(\mathrm{~s}$, $1 \mathrm{H}, \mathrm{ArH}), 10.15$ (s, 1H, NH). ${ }^{13} \mathrm{C}$ NMR $\left(75 \mathrm{MHz}, \mathrm{DMSO}-\mathrm{d}_{6}\right): \delta 11.1(2 \mathrm{xC}), 16.5(2 \times \mathrm{C}), 50.7$ $(2 \times C), 54.2(2 x C), 62.6,118.4,119.7,124.1\left(q, J_{1}=272.5 \mathrm{~Hz}\right), 125.9,128.7\left(q, J_{2}=31.0 \mathrm{~Hz}\right)$, $129.4,136.8(2 \times C), 140.6,153.6,173.6(2 \times C=O)$. HRMS (ESI) calc. for $\mathrm{C}_{21} \mathrm{H}_{21} \mathrm{~F}_{3} \mathrm{~N}_{6} \mathrm{O}_{2}[\mathrm{M}-\mathrm{H}]^{-}$: 445.4342 found: 445.4339 .

3.2.2. 2-((1-(2-Chlorophenyl)-1H-tetrazol-5-yl)amino)-4,5,6,7-tetramethyl-3a,4,7,7atetrahydro-1H-4,7-methanoisoindole-1,3(2H)-dione (2)

Yield 91\%. ${ }^{1} \mathrm{H}$ NMR (300 MHz, DMSO-d 6 ): $\delta 1.25\left(\mathrm{~d}, J=8.1 \mathrm{~Hz}, 1 \mathrm{H}, \mathrm{CH}_{2}\right), 1.38(\mathrm{~s}, 6 \mathrm{H}$, $\left.2 \mathrm{xCH}_{3}\right), 1.47\left(\mathrm{~d}, \mathrm{~J}=8.4 \mathrm{~Hz}, 1 \mathrm{H}, \mathrm{CH}_{2}\right), 1.51\left(\mathrm{~s}, 6 \mathrm{H}, 2 \mathrm{xCH}_{3}\right), 3.06(\mathrm{~s}, 2 \mathrm{H}, 2 \mathrm{CH}), 7.59-7.74$ (m, 3H, ArH), 7.79-7.82 (m, 1H, ArH), 10.21 (s, 1H, NH). ${ }^{13} \mathrm{C}$ NMR (75 MHz, DMSO-d 6 ): $\delta 11.1(2 \times C), 16.6(2 \times C), 50.7(2 \times C), 54.2(2 \times C), 62.6,128.7,129.7,129.7,130.7,131.2,133.0$, $136.8(2 \times C), 153.7,173.6(2 \times C=\mathrm{O})$. HRMS (ESI) calc. for $\mathrm{C}_{20} \mathrm{H}_{21} \mathrm{ClN}_{6} \mathrm{O}_{2}[\mathrm{M}-\mathrm{H}]^{-}: 412.8780$ found: 412.8782 .

3.2.3. 2-((1-(2-Bromophenyl)-1H-tetrazol-5-yl)amino)-4,5,6,7-tetramethyl-3a,4,7,7atetrahydro-1H-4,7-methanoisoindole-1,3(2H)-dione (3)

Yield 75\%. ${ }^{1} \mathrm{H}$ NMR (300 MHz, DMSO-d 6 ): $\delta 1.25\left(\mathrm{~d}, J=8.1 \mathrm{~Hz}, 1 \mathrm{H}, \mathrm{CH}_{2}\right), 1.37(\mathrm{~s}, 6 \mathrm{H}$, $\left.2 \times \mathrm{CH}_{3}\right), 1.47\left(\mathrm{~d}, \mathrm{~J}=8.4 \mathrm{~Hz}, 1 \mathrm{H}, \mathrm{CH}_{2}\right), 1.50\left(\mathrm{~s}, 6 \mathrm{H}, 2 \mathrm{xCH}_{3}\right), 3.05(\mathrm{~s}, 2 \mathrm{H}, 2 \mathrm{CH}), 7.61-7.67$ (m, 3H, ArH) $7.92-7.95$ (m, 1H, ArH), 10.15 (s, 1H, NH). ${ }^{13} \mathrm{C} \mathrm{NMR} \mathrm{(75} \mathrm{MHz,} \mathrm{DMSO-d} 6$ ): $\delta 11.1(2 \times C), 16.5(2 \times C), 50.7(2 \times C), 54.2(2 \times C), 62.6,121.3,129.3,129.8,131.3,133.1,133.8$, $136.8(2 \times C), 153.6,173.6(2 \times C=\mathrm{O})$. HRMS (ESI) calc. for $\mathrm{C}_{20} \mathrm{H}_{21} \mathrm{BrN}_{6} \mathrm{O}_{2}[\mathrm{M}-\mathrm{H}]^{-}: 457.3320$ found: 457.3323 .

3.2.4. 4,5,6,7-Tetramethyl-2-((1-(4-nitrophenyl)-1H-tetrazol-5-yl)amino)-3a,4,7,7atetrahydro-1H-4,7-methanoisoindole-1,3(2H)-dione (4)

Yield 71\%. ${ }^{1} \mathrm{H}$ NMR (300 MHz, DMSO-d 6 ): $\delta 1.33\left(\mathrm{~d}, J=8.4 \mathrm{~Hz}, 1 \mathrm{H}, \mathrm{CH}_{2}\right), 1.45(\mathrm{~s}, 6 \mathrm{H}$, $\left.2 \times \mathrm{CH}_{3}\right), 1.53\left(\mathrm{~s}, 6 \mathrm{H}, 2 \mathrm{CH}_{3}\right), 1.67\left(\mathrm{~d}, J=8.4 \mathrm{~Hz}, 1 \mathrm{H}, \mathrm{CH}_{2}\right), 3.48(\mathrm{~s}, 2 \mathrm{H}, 2 \mathrm{CH}), 7.81-7.86$ (m, 2H, ArH) , 8.30-8.35 (m, 2H, ArH), 10.74 (s, 1H, NH). ${ }^{13} \mathrm{C} \mathrm{NMR} \mathrm{(75} \mathrm{MHz,} \mathrm{DMSO-d} 6$ ): $\delta 10.6(2 \times C), 16.2(2 \times C), 51.7(2 \times C), 55.4(2 \times C), 62.0,117.8(2 \times C), 125.5(2 \times C), 137.2(2 \times C)$, $142.1,144.1,150.7,171.5(2 \times C=\mathrm{O})$. HRMS (ESI) calc. for $\mathrm{C}_{20} \mathrm{H}_{21} \mathrm{~N}_{7} \mathrm{O}_{4}[\mathrm{M}-\mathrm{H}]^{-}: 422.4330$ found: 422.4327

3.2.5. 4,5,6,7-Tetramethyl-2-((1-(p-tolyl)-1H-tetrazol-5-yl)amino)-3a,4,7,7a-tetrahydro-1H4,7-methanoisoindole-1,3(2H)-dione (5)

Yield 82\%. ${ }^{1} \mathrm{H}$ NMR (300 MHz, DMSO-d 6 ): $\delta 1.24\left(\mathrm{~d}, J=8.1 \mathrm{~Hz}, 1 \mathrm{H}, \mathrm{CH}_{2}\right), 1.38(\mathrm{~s}, 6 \mathrm{H}$, $\left.2 \mathrm{xCH}_{3}\right), 1.48\left(\mathrm{~d}, J=8.4 \mathrm{~Hz}, 1 \mathrm{H}, \mathrm{CH}_{2}\right), 1.51\left(\mathrm{~s}, 6 \mathrm{H}, 2 \mathrm{CH}_{3}\right), 2.42\left(\mathrm{~s}, 3 \mathrm{H}, \mathrm{CH}_{3}\right), 3.08(\mathrm{~s}, 2 \mathrm{H}$, 2xCH), 7.45 (s, 4H, ArH), 10.07 (s, 1H, NH). ${ }^{13} \mathrm{C}$ NMR (75 MHz, DMSO-d 6 ): $\delta 11.1(2 \times C)$, 
$16.6(2 \times C), 20.8,50.7(2 \times C), 54.2(2 \times C), 62.6,124.6(2 \times C), 130.0,130.4(2 \times C), 136.8(2 \times C), 140.2$, 153.7, $173.6(2 \times C=\mathrm{O})$. HRMS (ESI) calc. for $\mathrm{C}_{21} \mathrm{H}_{24} \mathrm{~N}_{6} \mathrm{O}_{2}[\mathrm{M}-\mathrm{H}]^{-}: 391.4630$ found: 391.4632.

3.2.6. 4,5,6,7-Tetramethyl-2-((1-phenyl-1H-tetrazol-5-yl)amino)-3a,4,7,7a-tetrahydro-1H4,7-methanoisoindole-1,3(2H)-dione (6)

Yield 93\%. ${ }^{1} \mathrm{H}$ NMR (300 MHz, DMSO-d 6 ): $\delta 1.25\left(\mathrm{~d}, J=8.1 \mathrm{~Hz}, 1 \mathrm{H}, \mathrm{CH}_{2}\right), 1.37(\mathrm{~s}, 6 \mathrm{H}$, $\left.2 \mathrm{xCH}_{3}\right), 1.47\left(\mathrm{~d}, J=8.4 \mathrm{~Hz}, 1 \mathrm{H}, \mathrm{CH}_{2}\right), 1.50\left(\mathrm{~s}, 6 \mathrm{H}, 2 \mathrm{CH}_{3}\right), 3.06(\mathrm{~s}, 2 \mathrm{H}, 2 \mathrm{CCH}), 7.55-7.58$ $(\mathrm{m}, 2 \mathrm{H}, \mathrm{ArH}), 7.62-7.69$ (m, 3H, ArH), 10.16 (s, 1H, NH). ${ }^{13} \mathrm{C} \mathrm{NMR}\left(75 \mathrm{MHz}, \mathrm{DMSO}-\mathrm{d}_{6}\right)$ : $\delta 11.1(2 \times C), 16.6(2 \times C), 50.7(2 \times C), 54.2(2 \times C), 62.6,124.7(2 \times C), 130.0(2 \times C), 130.3,132.5$, $136.8(2 \times C), 153.6,173.6(2 \times C=\mathrm{O})$. HRMS (ESI) calc. for $\mathrm{C}_{20} \mathrm{H}_{22} \mathrm{~N}_{6} \mathrm{O}_{2}[\mathrm{M}-\mathrm{H}]^{-}: 377.4360$ found: 377.4358 .

3.2.7. 2-((1-(2-Chlorophenyl)-1H-tetrazol-5-yl)amino)-4-isopropyl-7-methyl-3a,4,7,7atetrahydro-1H-4,7-ethanoisoindole-1,3(2H)-dione (7)

Yield 81\%. ${ }^{1} \mathrm{H}$ NMR (300 MHz, DMSO-d 6 ): $\delta 0.93\left(\mathrm{~d}, J=6.9 \mathrm{~Hz}, 3 \mathrm{H}, \mathrm{CH}_{3}\right), 1.03(\mathrm{~d}$, $\left.J=6.9 \mathrm{~Hz}, 3 \mathrm{H}, \mathrm{CH}_{3}\right), 1.14-1.25\left(\mathrm{~m}, 2 \mathrm{H}, \mathrm{CH}_{2}\right), 1.38\left(\mathrm{~s}, 3 \mathrm{H}, \mathrm{CH}_{3}\right), 1.44-1.58\left(\mathrm{~m}, 2 \mathrm{H}, \mathrm{CH}_{2}\right)$, 2.39-2.48 (m, 1H, CH), $2.80(\mathrm{~d}, J=8.1 \mathrm{~Hz}, 1 \mathrm{H}, \mathrm{CH}), 3.10(\mathrm{~d}, J=8.1 \mathrm{~Hz}, 1 \mathrm{H}, \mathrm{CH}), 5.88(\mathrm{~d}$, $J=8.4 \mathrm{~Hz}, 1 \mathrm{H}, \mathrm{CH}), 5.96(\mathrm{~d}, J=8.4 \mathrm{~Hz}, 1 \mathrm{H}, \mathrm{CH}), 7.56-7.73(\mathrm{~m}, 3 \mathrm{H}, \mathrm{ArH}), 7.78-7.82(\mathrm{~m}, 1 \mathrm{H}$, ArH), 10.20 (s, 1H, NH). ${ }^{13} \mathrm{C}$ NMR $\left(75 \mathrm{MHz}, \mathrm{DMSO}-\mathrm{d}_{6}\right): \delta 16.8,18.2,22.3,22.4,29.3,33.5$, 36.3, 43.1, 44.2, 47.8, 128.7, 129.7, 129.7, 130.7, 131.2, 133.0, 135.3, 136.3, 154.5, 173.1, 173.6.

HRMS (ESI) calc. for $\mathrm{C}_{21} \mathrm{H}_{23} \mathrm{ClN}_{6} \mathrm{O}_{2}[\mathrm{M}-\mathrm{H}]^{-}$: 425.9050 found: 425.9049.

3.2.8. 4-Isopropyl-7-methyl-2-((1-(4-nitrophenyl)-1H-tetrazol-5-yl)amino)-3a,4,7,7atetrahydro-1H-4,7-ethanoisoindole-1,3(2H)-dione (8)

Yield 74\%. ${ }^{1} \mathrm{H}$ NMR (500 MHz, DMSO-d $\left.)_{6}\right): \delta 0.95\left(\mathrm{~d}, J=6.5 \mathrm{~Hz}, 3 \mathrm{H}, \mathrm{CH}_{3}\right), 1.07(\mathrm{~d}$, $\left.J=7.0 \mathrm{~Hz}, 3 \mathrm{H}, \mathrm{CH}_{3}\right), 1.17-1.24\left(\mathrm{~m}, 2 \mathrm{H}, \mathrm{CH}_{2}\right), 1.43\left(\mathrm{~s}, 3 \mathrm{H}, \mathrm{CH}_{3}\right), 1.51-1.62\left(\mathrm{~m}, 2 \mathrm{H}, \mathrm{CH}_{2}\right)$, 2.41-2.45 (m, 1H, CH), $3.15(\mathrm{~d}, J=8.0 \mathrm{~Hz}, 1 \mathrm{H}, \mathrm{CH}), 3.39(\mathrm{~d}, J=8.0 \mathrm{~Hz}, 1 \mathrm{H}, \mathrm{CH}), 6.05(\mathrm{~d}$, $J=8.5 \mathrm{~Hz}, 1 \mathrm{H}, \mathrm{CH}), 6.14(\mathrm{~d}, J=8.5 \mathrm{~Hz}, 1 \mathrm{H}, \mathrm{CH}), 7.86(\mathrm{~d}, J=9.0 \mathrm{~Hz}, 2 \mathrm{H}, \mathrm{ArH}), 8.31(\mathrm{~d}$, $J=9.5 \mathrm{~Hz}, 2 \mathrm{H}, \mathrm{ArH}), 10.76$ (s, 1H, NH). ${ }^{13} \mathrm{C}$ NMR $\left(125 \mathrm{MHz}, \mathrm{DMSO}-\mathrm{d}_{6}\right): \delta 16.7,18.1,22.1$, 22.3, 29.3, 33.1, 36.7, 43.5, 45.4, 48.8, 117.9 (2xC), 125.3, 125.5, 135.5, 136.6, 142.2, 144.1, 150.5, $170.9,171.4$. HRMS (ESI) calc. for $\mathrm{C}_{21} \mathrm{H}_{23} \mathrm{~N}_{7} \mathrm{O}_{4}[\mathrm{M}-\mathrm{H}]^{-}: 436.4600$ found: 436.4602 .

3.2.9. 2-((1-(2-Bromophenyl)-1H-tetrazol-5-yl)amino)-4-isopropyl-7-methyl-3a,4,7,7atetrahydro-1H-4,7-ethanoisoindole-1,3(2H)-dione (9)

Yield 81\%. ${ }^{1} \mathrm{H}$ NMR (300 MHz, DMSO-d 6 ): $\delta 0.93\left(\mathrm{~d}, J=6.9 \mathrm{~Hz}, 3 \mathrm{H}, \mathrm{CH}_{3}\right), 1.03(\mathrm{~d}$ $\left.J=6.6 \mathrm{~Hz}, 3 \mathrm{H}, \mathrm{CH}_{3}\right), 1.14-1.25\left(\mathrm{~m}, 2 \mathrm{H}, \mathrm{CH}_{2}\right), 1.38\left(\mathrm{~s}, 3 \mathrm{H}, \mathrm{CH}_{3}\right), 1.44-1.58\left(\mathrm{~m}, 2 \mathrm{H}, \mathrm{CH}_{2}\right)$, 2.39-2.48 (m, 1H, CH), $2.80(\mathrm{~d}, J=8.1 \mathrm{~Hz}, 1 \mathrm{H}, \mathrm{CH}), 3.10(\mathrm{~d}, J=8.1 \mathrm{~Hz}, 1 \mathrm{H}, \mathrm{CH}), 5.88(\mathrm{~d}$, $J=8.4 \mathrm{~Hz}, 1 \mathrm{H}, \mathrm{CH}), 5.96(\mathrm{~d}, J=8.4 \mathrm{~Hz}, 1 \mathrm{H}, \mathrm{CH}), 7.61-7.67(\mathrm{~m}, 3 \mathrm{H}, \mathrm{ArH}), 7.92-7.95(\mathrm{~m}, 1 \mathrm{H}$, ArH), 10.16 (s, 1H, NH). ${ }^{13} \mathrm{C}$ NMR $\left(75 \mathrm{MHz}, \mathrm{DMSO}_{6}\right): \delta 16.8,18.2,22.3,22.4,29.3,33.5$, 36.3, 43.1, 44.2, 47.8, 121.4, 129.3, 129.8, 131.3, 133.1, 133.8, 135.3, 136.3, 154.3, 173.1, 173.5 .

HRMS (ESI) calc. for $\mathrm{C}_{20} \mathrm{H}_{21} \mathrm{BrN}_{6} \mathrm{O}_{2}[\mathrm{M}-\mathrm{H}]^{-}: 456.3320$ found: 456.3318 .

3.2.10. 4-Isopropyl-7-methyl-2-((1-(p-tolyl)-1H-tetrazol-5-yl)amino)-3a,4,7,7a-tetrahydro$1 \mathrm{H}-4,7$-ethanoisoindole-1,3(2H)-dione (10)

Yield 90\%. ${ }^{1} \mathrm{H}$ NMR (300 MHz, DMSO-d 6 ): $\delta 0.93\left(\mathrm{~d}, J=6.9 \mathrm{~Hz}, 3 \mathrm{H}, \mathrm{CH}_{3}\right), 1.03(\mathrm{~d}$, $\left.J=6.6 \mathrm{~Hz}, 3 \mathrm{H}, \mathrm{CH}_{3}\right), 1.11-1.25\left(\mathrm{~m}, 2 \mathrm{H}, \mathrm{CH}_{2}\right), 1.38\left(\mathrm{~s}, 3 \mathrm{H}, \mathrm{CH}_{3}\right), 1.48-1.58\left(\mathrm{~m}, 2 \mathrm{H}, \mathrm{CH}_{2}\right)$, 2.39-2.46 (m, 4H, $\mathrm{CH}_{3}$ and $\left.\mathrm{CH}\right), 2.90(\mathrm{~d}, J=8.1 \mathrm{~Hz}, 1 \mathrm{H}, \mathrm{CH}), 3.09(\mathrm{~d}, J=7.8 \mathrm{~Hz}, 1 \mathrm{H}, \mathrm{CH})$, $5.87(\mathrm{~d}, J=8.4 \mathrm{~Hz}, 1 \mathrm{H}, \mathrm{CH}), 5.95$ (d, $J=8.7 \mathrm{~Hz}, 1 \mathrm{H}, \mathrm{CH}), 7.45$ (s, 4H, ArH), 10.12 (s, 1H, $\mathrm{NH}) .{ }^{13} \mathrm{C}$ NMR $\left(75 \mathrm{MHz}, \mathrm{DMSO}-\mathrm{d}_{6}\right): \delta 16.7,18.2,22.3,22.4,29.3,33.5,36.3,43.1,44.3,47.8$, 124.5 (2xC), 129.9, $130.3(2 \times C), 135.2,136.2,140.1,153.7,173.3,173.7$. HRMS (ESI) calc. for $\mathrm{C}_{22} \mathrm{H}_{26} \mathrm{~N}_{6} \mathrm{O}_{2}[\mathrm{M}-\mathrm{H}]^{-}$: 405.4900 found: 405.4903. 
3.2.11. 4-Isopropyl-7-methyl-2-((1-phenyl-1H-tetrazol-5-yl)amino)-3a,4,7,7a-tetrahydro1H-4,7-ethanoisoindole-1,3(2H)-dione (11)

Yield 94\%. ${ }^{1} \mathrm{H}$ NMR (300 MHz, DMSO-d 6 ): $\delta 0.93\left(\mathrm{~d}, J=6.0 \mathrm{~Hz}, 3 \mathrm{H}, \mathrm{CH}_{3}\right), 1.03(\mathrm{~d}$, $\left.J=6.3 \mathrm{~Hz}, 3 \mathrm{H}, \mathrm{CH}_{3}\right), 1.15-1.25\left(\mathrm{~m}, 2 \mathrm{H}, \mathrm{CH}_{2}\right), 1.39\left(\mathrm{~s}, 3 \mathrm{H}, \mathrm{CH}_{3}\right), 1.47-1.58\left(\mathrm{~m}, 2 \mathrm{H}, \mathrm{CH}_{2}\right)$, 2.40-2.46 (m, 1H, CH), $2.79(\mathrm{~d}, J=7.8 \mathrm{~Hz}, 1 \mathrm{H}, \mathrm{CH}), 3.09(\mathrm{~d}, J=7.5 \mathrm{~Hz}, 1 \mathrm{H}, \mathrm{CH}), 5.88(\mathrm{~d}$, $J=8.4 \mathrm{~Hz}, 1 \mathrm{H}, \mathrm{CH}), 5.96(\mathrm{~d}, J=8.1 \mathrm{~Hz}, 1 \mathrm{H}, \mathrm{CH}), 7.57-7.69(\mathrm{~m}, 5 \mathrm{H}, \mathrm{ArH}), 10.21(\mathrm{~s}, 1 \mathrm{H}$, $\mathrm{NH}) .{ }^{13} \mathrm{C}$ NMR $(75 \mathrm{MHz}$, DMSO-d 6 ): $\delta 16.8,18.2,22.3,22.4,29.3,33.4,36.3,43.1,44.3,47.8$, $124.6(2 \times C), 130.0(2 \times C), 130.2,132.4,135.2,136.2,153.7,173.3,173.7$. HRMS (ESI) calc. for $\mathrm{C}_{21} \mathrm{H}_{24} \mathrm{~N}_{6} \mathrm{O}_{2}[\mathrm{M}-\mathrm{H}]^{-}: 391.4630$ found: 391.4628.

\subsection{Biological Assays}

The antimicrobial assays were conducted using reference strains of bacteria derived from international microbe collections: American Type Culture Collection (ATCC) and National Collection of Type Culture (NCTC). The following standard strains of bacteria were used: Gram-positive-Staphylococcus aureus NCTC 4163, Staphylococcus aureus ATCC 25923, Staphylococcus aureus ATCC 6538, Staphylococcus aureus ATCC 29213, Staphylococcus epidermidis ATCC 12228, Staphylococcus epidermidis ATCC 35984, Gram-negative: Escherichia coli ATCC 25922, Pseudomonas aeruginosa ATCC 15442. Clinical strains of bacteria used in this study: Grampositive: Staphylococcus epidermidis 5253, Staphylococcus epidermidis 4243, Staphylococcus aureus T5592, Staphylococcus aureus T5591 and Gram-negative: Escherichia coli 520, Escherichia coli 600, Klebsiella pneumoniae 510 and Pseudomonas aeruginosa 659 were obtained from the collection of the Department of Pharmaceutical Microbiology, Medical University of Warsaw, Poland and they were isolated from different biological materials taken from the patients hospitalized in the Warsaw Medical University hospitals. Antimicrobial activity was examined by the minimal inhibitory concentration (MIC) method under standard procedures provided by CLSI with some modifications. MIC was determined by the two-fold serial broth microdilution method in 96-well microtitration plates using Mueller-Hinton II broth medium (Becton Dickinson, Franklin Lakes, NJ, USA). The final inoculum of all studied bacteria was $10^{6} \mathrm{CFU} / \mathrm{mL}$ (colony forming unit per milliliter). The stock solution of tested compounds was prepared in dimethyl sulfoxide (DMSO) and diluted to a maximum of $1 \%$ of solvent content with a sterile medium. The MIC value recorded is defined as the lowest concentration of the tested antimicrobial agents (expressed in $\mu \mathrm{g} / \mathrm{mL}$ ) that inhibit the visible growth of the microorganism after $19 \mathrm{~h}$ of incubation at $35^{\circ} \mathrm{C}$.

Description related to conducted biological studies including cell culture, suitable conditions, and methodology was presented in our previous paper [34].

\subsection{Molecular Docking Studies}

The molecular docking procedure was as follows. First, the ligand structures were generated using the Automated Topology Builder server (ATB version 2.2) [35]. Docking calculations and data analysis were performed using AutoDock4 (v. 4.2) and AutoDockTools4 [36]. For each receptor-ligand complex, 1000 independent docking cycles were performed, resulting in 1000 conformers with the lowest binding energy. Next, structural clustering was used to identify the most preferred binding modes (with RMSD cut-off of $3 \AA$ ). Finally, the central structure of the largest cluster was selected as the final liganddocked structure for each complex.

\section{Conclusions}

The transition presented here from imide-thiourea substrates, thoroughly studied in our previous works [22-25], to appropriate novel imide-tetrazole products was successfully performed in the course of a single reaction. All synthesized compounds were tested in vitro against a set of bacteria, including representative standard Gram-positive and Gramnegative rods. Transition from substrate imide-thioureas to imide-tetrazoles increased antimicrobial properties of obtained derivatives. Compounds 1, 2, and 3 possessing strong $\left(-\mathrm{CF}_{3}\right)$ and weak $(-\mathrm{Br},-\mathrm{Cl})$ deactivating electron-withdrawing substituents in the benzene 
ring turned out to have the highest antimicrobial potential of all tested compounds against standard and clinical strains of bacteria. Lead compounds 1, 2, 3 were transferred for further testing to establish the mechanism of antimicrobial action. Those were examined in topoisomerase IV decatenation assay and DNA gyrase supercoiling assay. Obtained results suggest that there is a higher affinity towards the DNA gyrase of synthesized derivatives. We also conducted molecular docking of the studied compounds to gain some insight into the possible binding modes. The molecular docking to the fluoroquinolone binding site showed that the narrow binding cleft is not well-suited to the docked ligands. In the second stage, we targeted the ATP-binding site of the B subunit of DNA gyrase with Novobiocin as the best-studied representative. In comparison to the Novobiocin-binding mode, the ligands mainly bind to the gyrase site that is responsible for interactions with the sugar Novobiocin moiety.

Summarizing, the presented transition from substrate imide-thioureas to imide-tetrazole derivatives resulted in significant increase of antimicrobial properties. The compounds 1-3 proposed here provide a promising basis for further exploration towards novel antimicrobial drug candidates.

Author Contributions: P.R. completed the spectral data analyses and wrote part of manuscript. J.S.-M. conducted antimicrobial evaluation of compounds. M.K. conducted experiment for molecular docking studies. S.K. provided results interpretation and visuals for molecular docking. M.W. conducted topoisomerases studies. M.S. was the principal investigator of the project and provided the research funding. D.S. performed the syntheses of compounds and wrote the manuscript. All authors have read and agreed to the published version of the manuscript.

Funding: This research received no external funding.

Institutional Review Board Statement: Not applicable.

Informed Consent Statement: Not applicable.

Data Availability Statement: Not applicable.

Conflicts of Interest: The authors declare no conflict of interest.

\section{References}

1. Munita, J.M.; Arias, C.A. Mechanisms of Antibiotic Resistance. Microbiol. Spectr. 2016, 4, 1-37. [CrossRef] [PubMed]

2. Fajardo, A.; Martinez-Martin, N.; Mercadillo, M.; Galan, J.C.; Ghysels, B.; Matthijs, S.; Cornelis, P.; Wiehlmann, L.; Tümmler, B.; Baquero, F.; et al. The neglected intrinsic resistome of bacterial pathogens. PLoS ONE 2008, 3, e1619. [CrossRef] [PubMed]

3. Cox, G.; Wright, G.D. Intrinsic antibiotic resistance: Mechanisms, origins, challenges and solutions. Int. J. Med. Microbiol. 2013, 303, 287-292. [CrossRef] [PubMed]

4. Wright, G.D. The antibiotic resistome: The nexus of chemical and genetic diversity. Nat. Rev. Microbiol. 2007, 5, 175-186. [CrossRef] [PubMed]

5. $\quad$ Bismuth, R.; Zilhao, R.; Sakamoto, H.; Guesdon, J.L.; Courvalin, P. Gene heterogeneity for tetracycline resistance in Staphylococcus spp. Antimicrob. Agents Chemother. 1990, 34, 1611-1614. [CrossRef]

6. van Hoek, A.; Mevius, D.; Guerra, B.; Mullany, P.; Roberts, A.; Aarts, H. Acquired antibiotic resistance genes: An overview. Front. Microbiol. 2011, 2, 203. [CrossRef] [PubMed]

7. Dantas, G.; Sommer, M.O. Context matters-The complex interplay between resistome genotypes and resistance phenotypes. Curr. Opin. Microbiol. 2012, 15, 577-582. [CrossRef] [PubMed]

8. Martinez, J.L. Ecology and evolution of chromosomal gene transfer between environmental microorganisms and pathogens. Microbiol. Spectr. 2018, 6, 1-16. [CrossRef]

9. Reygaert, W.C. An overview of the antimicrobial resistance mechanisms of bacteria. AIMS Microbiol. 2018, 4, 482-501. [CrossRef] [PubMed]

10. Peterson, E.; Kaur, P. Antibiotic Resistance Mechanisms in Bacteria: Relationships Between Resistance Determinants of Antibiotic Producers, Environmental Bacteria, and Clinical Pathogens. Front. Microbiol. 2018, 9, 2928. [CrossRef] [PubMed]

11. Lowy, F.D. Staphylococcus aureus infections. N. Engl. J. Med. 1998, 339, 520-532. [CrossRef] [PubMed]

12. Waldvogel, F.A. Staphylococcus aureus (including Staphylococcal Toxic Shock). In Principles and Practice of Infectious Diseases; Mandell, G.L., Bennett, J.E., Dolin, R., Eds.; Churchill Livingstone: Philadelphia, PA, USA, 2000; pp. $2069-2092$.

13. Mylotte, J.M.; McDermott, C.; Spooner, J.A. Prospective study of 114 consecutive episodes of Staphylococcus aureus bacteremia. Rev. Infect. Dis. 1987, 9, 891-907. [CrossRef] [PubMed] 
14. Lowy, F.D. Antimicrobial resistance: The example of Staphylococcus aureus. J. Clin. Investig. 2003, 111, 1265-1273. [CrossRef] [PubMed]

15. Abushaheen, M.A.; Muzaheed; Fatani, A.J.; Alosaimi, M.; Mansy, W.; George, M.; Acharya, S.; Rathod, S.; Divakar, D.D.; Jhugroo, C.; et al. Antimicrobial resistance, mechanisms and its clinical significance. Dis. Mon. 2020, 66, 100971. [CrossRef]

16. Blair, J.; Webber, M.; Baylay, A.; Ogbolu, D.O.; Piddock, L.J.V. Molecular mechanisms of antibiotic resistance. Nat. Rev. Microbiol. 2015, 13, 42-51. [CrossRef] [PubMed]

17. Bbosa, G.; Mwebaza, N.; Odda, J.; Kyegombe, D.; Ntale, M. Antibiotics/antibacterial drug use, their marketing and promotion during the post-antibiotic golden age and their role in emergence of bacterial resistance. Health 2014, 6, 410-425. [CrossRef]

18. Holmes, A.H.; Moore, L.S.; Sundsfjord, A.; Steinbakk, M.; Regmi, S.; Karkey, A.; Guerin, P.J.; Piddock, L.J. Understanding the mechanisms and drivers of antimicrobial resistance. Lancet 2016, 387, 176-187. [CrossRef]

19. Poole, K. Overcoming antimicrobial resistance by targeting resistance mechanisms. J. Pharm. Pharmacol. 2001, 53, 283-294. [CrossRef]

20. Ruppé, É.; Woerther, P.L.; Barbier, F. Mechanisms of antimicrobial resistance in Gram-negative bacilli. Ann. Intensive Care 2015, 5, 61. [CrossRef] [PubMed]

21. Watkins, R.R.; Holubar, M.; David, M.Z. Antimicrobial resistance in methicillin-resistant Staphylococcus aureus to newer antimicrobial agents. Antimicrob. Agents Chemother. 2019, 63, e01216-e01219. [CrossRef] [PubMed]

22. Bielenica, A.; Szulczyk, D.; Olejarz, W.; Madeddu, S.; Giliberti, G.; Materek, I.B.; Koziol, A.E.; Struga, M. 1H-Tetrazol-5-Amine and 1,3-Thiazolidin-4-One Derivatives Containing 3-(Trifluoromethyl)Phenyl Scaffold: Synthesis, Cytotoxic and Anti-HIV Studies. Biomed. Pharmacother. 2017, 94, 804-812. [CrossRef] [PubMed]

23. Szulczyk, D.; Bielenica, A.; Głogowska, A.; Augustynowicz-Kopeć, E.; Dobrowolski, M.; Roszkowski, P.; Stępień, K.; Chrzanowska, A.; Struga, M. Development of (4-Methoxyphenyl)-1H-Tetrazol-5-Amine Regioisomers as a New Class of Selective Antitubercular Agents. Eur. J. Med. Chem. 2020, 186, 111882. [CrossRef]

24. Szulczyk, D.; Bielenica, A.; Roszkowski, P.; Dobrowolski, M.A.; Olejarz, W.; Napiórkowska, M.; Struga, M. Cytotoxicity Evaluation of Novel Bis(2-aminoethyl)amine Derivatives. Molecules 2020, 25, 2816. [CrossRef] [PubMed]

25. Szulczyk, D.; Bielenica, A.; Roszkowski, P.; Dobrowolski, M.A.; Olejarz, W.; Kmiecik, S.; Podsiad, M.; Struga, M. Synthetic Transition from Thiourea-Based Compounds to Tetrazole Derivatives: Structure and Biological Evaluation of Synthesized New N-(Furan-2-ylmethyl)-1H-tetrazol-5-amine Derivatives. Molecules 2021, 26, 323. [CrossRef] [PubMed]

26. Szulczyk, D.; Bielenica, A.; Dobrowolski, M.A.; Dobrzycki, L.; Krawiecka, M.; Kuran, B.; Struga, M. Synthesis and structure evaluation of new complex butylarylpiperazin-1-yl derivatives. Med. Chem. Res. 2014, 23, 1519-1536. [CrossRef]

27. Dobrowolski, M.A.; Roszkowski, P.; Struga, M.; Szulczyk, D. The Unexpected Product of Diels-Alder Reaction between “Indanocyclon" and Maleimide. J. Mol. Struct. 2017, 1130, 573-578. [CrossRef]

28. Szulczyk, D.; Struga, M. 4-Hydroxy-1-methyl-7-(propan-2-yl)-4-azatricyclo[5.2.2.02,6]undec-8-ene-3,5-dione. Molbank 2012, 2012, M767. [CrossRef]

29. Bielenica, A.; Stefańska, J.; Kozioł, A.E.; Iuliano, F.; Collu, D.; Sanna, G.; Jóźwiak, M.; Struga, M. Thiourea Derivatives of 4Azatricyclo[5.2.2.0(2.6)]Undec-8-Ene-3,5-Dione-Synthesis and Biological Activity. Acta Pol. Pharm. 2016, 73, 693-703. [PubMed]

30. Struga, M.; Kossakowski, J.; Kedzierska, E.; Fidecka, S.; Stefańska, J. Synthesis and pharmacological activity of urea and thiourea derivatives of 4-azatricyclo[5.2.2.02,6] undec-8-ene-3,5-dione. Chem. Pharm. Bull. 2007, 55, 796-799. [CrossRef] [PubMed]

31. Pogodin, P.V.; Lagunin, A.A.; Rudik, A.V.; Druzhilovskiy, D.S.; Filimonov, D.A.; Poroikov, V.V. AntiBac-Pred: A Web Application for Predicting Antibacterial Activity of Chemical Compounds. J. Chem. Inf. Mod. 2019, 59, 4513-4518. [CrossRef] [PubMed]

32. Pires, D.E.V.; Blundell, T.L.; Ascher, D.B. PkCSM: Predicting Small-Molecule Pharmacokinetic and Toxicity Properties Using Graph-Based Signatures. J. Med. Chem. 2015, 58, 4066-4072. [CrossRef] [PubMed]

33. Approved Standard M7-a7. Clinical and Laboratory Standards Institute Methods for Dilution Antimicrobial Susceptibility Tests for Bacteria That Grow Aerobically; CLSI: Malvern, PA, USA, 2006.

34. Szulczyk, D.; Dobrowolski, M.A.; Roszkowski, P.; Bielenica, A.; Stefańska, J.; Koliński, M.; Kmiecik, S.; Jóźwiak, M.; Wrzosek, M.; Olejarz, W.; et al. Design and Synthesis of Novel 1H-Tetrazol-5-Amine Based Potent Antimicrobial Agents: DNA Topoisomerase IV and Gyrase Affinity Evaluation Supported by Molecular Docking Studies. Eur. J. Med. Chem. 2018, 156, 631-640. [CrossRef] [PubMed]

35. Malde, A.K.; Zuo, L.; Breeze, M.; Stroet, M.; Poger, D.; Nair, P.C.; Oostenbrink, C.; Mark, A.E. An Automated force field Topology Builder (ATB) and repository: Version 1.0. J. Chem. Theory Comput. 2011, 7, 4026-4037. [CrossRef] [PubMed]

36. Morris, G.M.; Huey, R.; Lindstrom, W.; Sanner, M.F.; Belew, R.K.; Goodsell, D.S.; Olson, A.J. Autodock4 and AutoDockTools4: Automated docking with selective receptor flexiblity. J. Comp. Chem. 2009, 16, 2785-2791. [CrossRef] [PubMed] 